\title{
Grazing by the intertidal gastropod Melampus coffeus greatly increases mangrove leaf litter degradation rates
}

\author{
C. Edward Proffitt*, Donna J. Devlin
}

Florida Atlantic University, c/o Harbor Branch Oceanographic Institution, 5600 US 1 North, Fort Pierce, Florida 34946, USA

\begin{abstract}
Melampus coffeus, a pulmonate gastropod, forages for mangrove leaf litter at low tide and climbs tree trunks to avoid inundation during high tide. Unlike many grazers, these snails can assimilate mangrove leaf material. At Boca Ceiga Bay, Florida, densities of adult snails were high (>100 snails $\mathrm{m}^{-2}$ ) throughout a $130 \mathrm{~m}$ wide intertidal zone. A mark-recapture study indicated that over the course of 1 mo $48.6 \pm 6.1 \%$ of snails returned to their initial tree during high tides, while those that did relocate moved $6.66 \pm 0.60 \mathrm{~m}$ and were recorded from 33 new trees at high tide. A field experiment comparing tethered leaves with small and large litter bags showed that snail grazing greatly increased the rate of red (Rhizophora mangle) and black (Avicennia germinans) leaf litter breakdown. Grazing by $M$. coffeus resulted in $90 \%$ weight loss in $<4$ wk (A. germinans) and 7 wk $(R$. mangle), compared to slower breakdown in litter bags (12 to $26 \mathrm{wk}, A$. germinans; $>26 \mathrm{wk}, R$. mangle). Another experiment showed greater leaf litter accumulation on the forest floor in plots where $M$. coffeus was excluded. The decomposition coefficient $(k)$ was $10 \times$ greater when $M$. coffeus grazing was allowed than $k$ for any studies that enclosed leaves in litterbags. During our experiment, $M$. coffeus consumed an estimated $40.5 \%$ of mangrove leaf fall, and $19.8 \%$ of leaf litter was exported as particulate or dissolved material. This $M$. coffeus population can produce an estimated $3 \times 10^{6}$ larvae $\mathrm{m}^{-2} \mathrm{yr}^{-1}$, which suggests that the larval pathway is an important conduit of mangrove leaf resources to the estuarine food web.
\end{abstract}

KEY WORDS: Mangrove $\cdot$ Detritivore $\cdot$ Decomposition $\cdot$ Rhizophora mangle $\cdot$ Avicennia germinans

Resale or republication not permitted without written consent of the publisher

\section{INTRODUCTION}

Despite considerable study, the linkages between mangrove forest detritus and adjacent estuarine water ecosystems are inadequately understood (Odum \& Heald 1972, Fell \& Master 1973, Snedaker \& Lugo 1973, Cundell et al. 1979, Twilley et al. 1986, Boto 1992, Holmer \& Olsen 2002). Proffitt et al. (1993) reported that grazing by the intertidal gastropod Melampus coffeus L. (Pulmonata: Ellobiidae) in both field and laboratory trials caused very high rates of breakdown of Rhizophora mangle, Avicennia germinans and Laguncularia racemosa leaves. They also found differences among mangrove species and with different degrees of leaf senescence (Proffitt et al. 1993) and were the first to suggest that grazing by invertebrates might account for a large fraction of leaf breakdown in Florida. This important animal-plant interaction was missed by earlier studies of decomposition that excluded $M$. coffeus and other large invertebrate grazers by studying litter enclosed within mesh bags (Heald 1969, 1971, Lugo \& Snedaker 1974, Twilley et al. 1986). Laboratory studies by Mook (1986) showed that $M$. coffeus could assimilate large fractions of fresh (79\%) and senescent (56\%) R. mangle leaves. McKee \& Faulkner (2000) found high rates of grazing by $M$. coffeus on mangrove leaf litter in both natural and restored forests in SW Florida.

Where Melampus coffeus has an abundant and persistent population in mangrove forests, a substantial fraction of mangrove leaf productivity can pass through a snail-mediated pathway to the estuary as 
snail biomass, larvae, and feces (Mook 1986, Proffitt et al. 1993). Thus, M. coffeus functions as more than just a shredder snail (sensu Newell 1965, Fenchel 1969, 1970, Newell \& Barlocher 1993, Barlocher \& Newell 1994). Clearly, differences in type of pathway and the rates of litter degradation in mangrove forests may affect predictions about the proportion of mangrove productivity that is re-cycled within the forest relative to that exported. The objectives of the present study were to further quantify the rates of $M$. coffeus grazing on Rhizophora mangle and Avicennia germinans leaf litter; to couple this with measurements of leaf litter fall and standing crop in order to estimate the rate of this grazing pathway per unit forest area; and to assess $M$. coffeus population densities over time and across the intertidal zone.

Melampus coffeus is abundant in many mangrove forests on both coasts of Florida (authors' pers. obs.) and is present and sometimes abundant elsewhere in the Caribbean (Golley 1960, Heard 1982). In Tampa Bay, $M$. coffeus and $M$. bidatentus co-occur, although the latter is more generally found in salt marshes (Mook 1973). Other studies have indicated the importance of $M$. coffeus in leaf breakdown in SW Florida (McKee \& Faulkner 2000) and have suggested that the snail may affect seedling distribution in mangrove forests by consuming Avicennia germinans (Smith et al. 1989). Also, other invertebrates can play significant roles in mangrove leaf litter breakdown (Poovachiranon et al. 1986). Crabs have been frequently reported to relocate leaf litter from the forest floor to their burrows in the Indo-Pacific (Macnae 1967, Van der Valk \& Attwill 1984, Leh \& Sasekumar 1985, Robertson 1986, Lee 1989, Robertson et al. 1992). The crabs then consume the leaves after allowing some time for microbial growth. When leaves are buried under sediment without crab intervention, decomposition is much slower (Holmer \& Olsen 2002). Twilley et al. (1997) reported that crabs were important in the removal of litter in some seasons in Ecuador.

Many ellobiid gastropods have a specialized gizzard and stomach system that allows a high efficiency of assimilation of plant matter consumed (Morton 1955). Some molluscs also tend to have a diverse complement of digestive enzymes, often including cellulases (Mason 1974). However the digestive enzymes of Melampus coffeus have not been studied. M. coffeus preferentially aggregates to green leaves over yellow and brown ones (Proffitt et al. 1993, present study field observations). However, M. coffeus apparently requires more time to break through the tough outer cuticle of green leaves. Consequently, there is a lag time before grazing effects are evident, whereas on yellow and brown leaves, grazing effects are seen within hours of exposure (Proffitt et al. 1993). This snail is an active grazer when the forest floor is exposed at low tide. It escapes being covered by water at high tide by climbing tree trunks, prop roots, taller seedlings, and various emergent debris. The timing of this behavioral rhythm was maintained a number of days when snails were brought in to the lab and kept without any tidal flux (authors' pers. obs.).

Litterfall occurs in seasonal and species specific patterns mainly as yellow senescent leaves, although substantial numbers of green leaves fall episodically during storms (authors' pers. obs.). The rates of grazing of Melampus coffeus vary by species and by degree of senescence of the leaves (Proffitt et al. 1993). Thus, the proportion of litter entering the system as green versus yellow leaves, the proportion of leaves that exist on the ground long enough to become brown, and the rates of breakdown of each leaf group all contribute to the nature and pattern of coupling of mangrove forests to adjacent open-water systems and should be considered in models of decomposition and nutrient cycling.

We report here on a $26 \mathrm{wk}$ field experiment of mangrove leaf breakdown in which mangrove leaves were either tethered and thus exposed to Melampus coffeus grazing, enclosed in individual small bags, or enclosed with a group of leaves in larger mesh bags that excluded $M$. coffeus. We also conducted a caging study in which litter and snails were removed from one group and litter but not snails from the other and the accumulation of leaf litter over 1 mo was tracked. The hypothesis tested in the first experiment was that leaves enclosed within bags would receive less grazing and therefore degrade less rapidly than tethered leaves exposed to $M$. coffeus. The hypothesis evaluated in the second associated experiment was that litter would accumulate more rapidly on sections of the forest floor that were fenced to eliminate grazing by $M$. coffeus. We also collected litterfall during the caging experiment and measured standing crop of litter in the forest over a $1.5 \mathrm{yr}$ period. Data on mangrove forest structure and $M$. coffeus population densities were also gathered. Grazing rates measured in the litterbag experiment and snail density data were applied to the data on litterfall and standing crop in order to estimate overall amounts of leaf degradation due to $M$. coffeus. The rate of snail movements around the forest were determined in a mark-recapture study to provide information on snail movement and foraging behavior.

\section{MATERIALS AND METHODS}

Forest structure, litter standing crop, and litterfall. The study was conducted in Boca Ciega Bay, part of the Tampa Bay estuary system, in the mixed species mangrove forest at War Veterans Park, Pinellas 
County, Florida (Fig. 1). Densities of canopy trees, their heights and diameters at breast height ( $\mathrm{DBH}$, measured at about $1.3 \mathrm{~m}$ above ground) were determined in $3 \times 3 \mathrm{~m}$ plots, at stations situated every $10 \mathrm{~m}$ along a $130 \mathrm{~m}$ long transect extending from shore $(0 \mathrm{~m})$ to the upland edge $(130 \mathrm{~m})$.

Leaf litter standing crop was collected at stations located 10, 50, and $120 \mathrm{~m}$ from shore in 5 replicate $30 \times$ $30 \mathrm{~cm}$ quadrats 4 times over a year in 1993. Leaf litterfall was collected twice during a $60 \mathrm{~d}$ period in the same location during one of the leaf breakdown studies during late summer. Three replicate $0.5 \times 0.5 \mathrm{~m}$ collectors made from plastic screen material $(1 \mathrm{~mm}$ mesh size) were used to collect leaf litterfall at the same location as the decomposition studies. Leaves were separated by species, and dry weights were determined for both standing crop and litterfall.

Melampus coffeus population densities. Melampus coffeus densities were recorded in replicate $20 \times 20 \mathrm{~cm}$ quadrats ( $\mathrm{n}=5$ to 10 ) at each station along the forest structure transect during low tide over 33 mo from 1992 to 1994 . Density values reported here include only overall transect means $( \pm 1 \mathrm{SD})$ of individuals with shell lengths $>4 \mathrm{~mm}$. Smaller individuals 1 to $4 \mathrm{~mm}$ in length were present in all months of the year. Separate from the adult population collections, we measured juvenile densities, along with those of adults, on the forest floor in $30 \times 30 \mathrm{~cm}$ quadrats $(\mathrm{n}=5)$ at 4 of the stations in February and May. Juvenile and adult densities (square-root-transformed) were analyzed by MANOVA with time (month) and station as independent variables. Also, all quadrats were subjected to paired $t$-test to determine whether mean adult versus juvenile densities differed. Adult and juvenile densities were tested to determine whether they were spatially correlated (Pearson product-moment correlation).

Patterns and rates of snail movement on the forest. We conducted a mark-recapture study of Melampus coffeus adults in order to determine their rates of movement around the forest at low tide. During a high tide in May 1993, all snails on 3 Avicennia germinans trees approximately $120 \mathrm{~m}$ from open water were marked with a different color paint for each tree. The numbers and locations of marked and total snails on tree trunks on subsequent high tides were determined, and the distance of these trees from the starting trees measured.

Leaf tethering and litterbag experiment. The site chosen for the experiment on decomposition of Rhizophora mangle and Avicennia germinans leaf litter was located 50 to $60 \mathrm{~m}$ into the forest from the shoreline. The leaf grazing experiment was initiated in June 1993 and ran for 26 wk. Main factors in the experiment were plant leaf species, grazing treatment, and

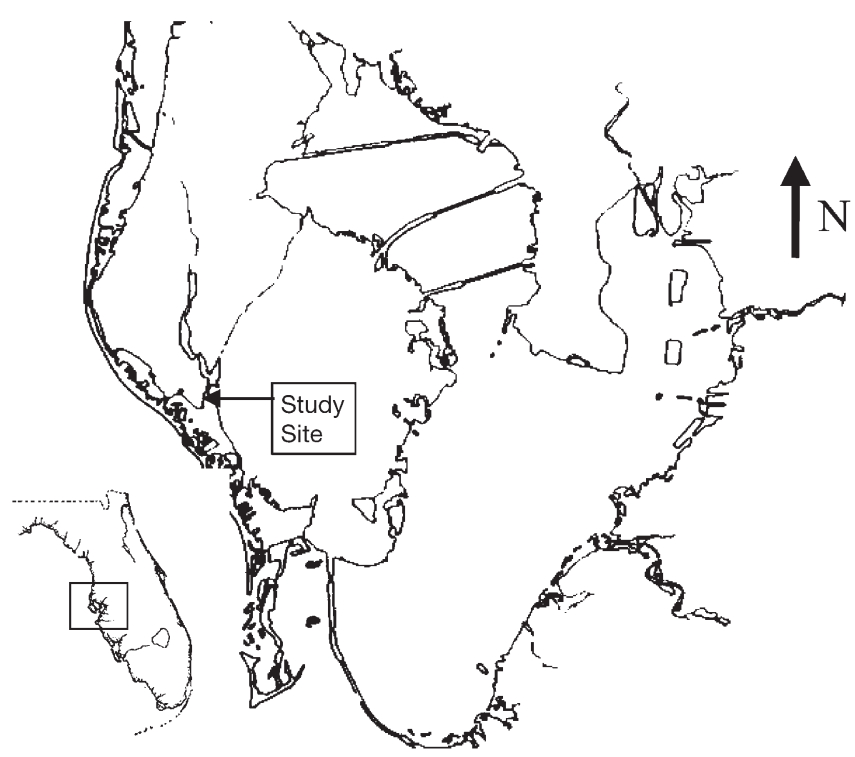

Fig. 1. Map of the Tampa Bay, Florida, estuarine system showing the location of the study site at War Veterans Park in Boca Ciega Bay $\left(27^{\circ} 48^{\prime} \mathrm{N}, 82^{\circ} 46^{\prime} \mathrm{W}\right)$. The state map (left) shows the location of Tampa Bay. Scale: $1 \mathrm{~cm}$ is approximately $1.6 \mathrm{~km}$

time. Leaves were collected from trees in the forest for use in the experiment. The grazing treatment had 3 levels: (1) unbagged, in which leaves were tethered by their petiole to a wooden stake via monofilament; (2) small litter bags, in which single leaves were enclosed in $10 \times 8 \mathrm{~cm}$ polypropylene bags held in a cylindrical shape by an internal lattice of larger gauge plastic mesh; and (3) large litter bags $(30 \times 30 \mathrm{~cm})$, into which $20 \mathrm{~g}$ of leaf material (either $R$. mangle or $A$. germinans) was placed. The internal lattice of plastic mesh was used to shape small bags into a cylinder, rather than allowing them to lay flat, in order to reduce the through-the-mesh grazing reported by Proffitt et al. (1993). All bags had a mesh size of $1 \mathrm{~mm}^{2}$. Bags were sewn shut with monofilament line. Unbagged (tethered) leaves and bags were tied to wooden stakes (4 to a stake) with $15 \mathrm{~cm}$ long strands of monofilament line. Stakes were marked and driven into the sediment at randomly assigned locations ranging from 50 to $60 \mathrm{~m}$ from shore, where the canopy was dominated mainly by A. germinans with a large number of subcanopy $R$. mangle trees. Sampling was conducted at 4, 7, 12, and 26 wk. Numbers of replicates collected during each sampling were: unbagged $=20$, small bags $=20$, and large bags $=5$. Senescing (yellowing) leaves were used in the experiment.

Collected leaves were carefully washed in the laboratory, and the leaf area showing visible decomposition was measured under a dissecting microscope 
following the procedures of Proffitt et al. (1993). This provided 2 measures: (1) areas of holes, where leaf material had completely disappeared, and (2) areas of translucence, where sections of leaves had become noticeably thinner generally (especially in earlier weeks) because of the grazing of layers of cells from the surface. The sum of these 2 measures gave the total area affected by grazing (Proffitt et al. 1993). Dry weight was measured $\left(48 \mathrm{~h}, 50^{\circ} \mathrm{C}\right)$ following area determinations. Dry weights of leaves that were not subjected to field treatments were also measured to allow calculation of percent weight loss occurring under degradation and grazing treatments.

Percent area (translucence and holes) and percent weight remaining were analyzed in a MANOVA with mangrove species, treatment, and time as independent variables. Percent data were arcsine-square-roottransformed following conversion to proportions.

Litter accumulation in cages with Melampus coffeus excluded. Open top cages $(61 \times 61 \mathrm{~cm}$ sides, $50 \mathrm{~cm}$ tall, $1 \mathrm{~mm}$ mesh size) were constructed at the site of the first experiment. In one set $(n=4)$ of cages, all litter and snails were removed initially, and any snails re-entering caged areas were removed during a daily check. In the other set of cages, litter was removed but snails were maintained at typical densities (114 snails $\mathrm{m}^{-2}$ ) by daily checks and addition of snails as needed. After $27 \mathrm{~d}$, all litter was collected from cages, dried and weighed. Mean leaf accumulation by dry weight in cages with and without snails was analyzed by Student's $t$-test.

Calculations and derived variables. Decomposition coefficient: The decomposition coefficient $(k)$ was calculated from:

$$
W_{t}=W_{0} \mathrm{e}^{-k t}
$$

where $W_{0}=$ initial dry weight, $W_{t}=$ dry weight remaining at time $t$.

Since the proportion of weight remaining is simply $P_{W}=W_{t} / W_{0}$, the equation to calculate $k$ can be written as:

$$
k=-\ln \left(P_{W}\right) / t
$$

$k$ was estimated by regressing the proportion weight remaining on time (in days).

Grazing rates: Leaves exposed to Melampus coffeus grazing were staked out among the natural leaf litter of the forest. Therefore, grazing rates calculated from the experimental leaves were applied to the standing crop of leaf litter to provide an estimate of the total amount of material consumed.

Amount consumed per day $\left(C_{\mathrm{g}}\right)=$ percent weight grazed/d $\times$ litter standing crop ( $\mathrm{g}$ dry wt $\mathrm{m}^{-2}$ ). This is a slight overestimate of the total grazing, since litter on the ground varies in age and thus probably palatability. However, Proffitt et al. (1993) showed that both yellow and brown leaves were consumed at somewhat similar rates after the first few weeks.

Daily leaf litterfall: The amount of the daily leaf litterfall $(L)$ that was consumed $\left(C_{\mathrm{LF}}\right)$ per day was calculated as: $C_{\mathrm{LF}}=L-C_{\mathrm{g}}$. Both $L$ and $C_{\mathrm{g}}$ are in $\mathrm{g} \mathrm{m}^{-2} \mathrm{~d}^{-1}$.

\section{RESULTS}

Melampus coffeus habitat description: forest structure, tidal flooding, litter standing crop, and litterfall

The intertidal region dominated by mangroves was $130 \mathrm{~m}$ from open water to upland edge. Unless otherwise specified, values presented in text and graphs are means and one standard deviation. The first $20 \mathrm{~m}$ was dominated by Rhizophora mangle (3.87 $\pm 0.86 \mathrm{~m}$ tall; DBH $4.2 \pm 1.0 \mathrm{~cm}$ ) (Fig. 2A). Avicennia germinans was dominant (Fig. 2A) from $30 \mathrm{~m}$ to the upland edge (height $5.12 \pm 1.78 \mathrm{~m}$; DBH $6.8 \pm 2.9 \mathrm{~cm}$ ). The region of the forest where leaf decomposition experiments took place was flooded by 252 tides $\mathrm{yr}^{-1}$ to monthly mean high depths ranging from $8.1 \pm 4.7$ to $13.2 \pm 5.5 \mathrm{~cm}$. The area near the mangrove-upland edge was flooded by 124 tides $\mathrm{yr}^{-1}$.

The leaf litter standing crop was about evenly split between Rhizophora mangle and Avicennia germinans leaves within $20 \mathrm{~m}$ of open water, but was $83 \%$ A. germinans and $17 \% R$. mangle for the rest of the
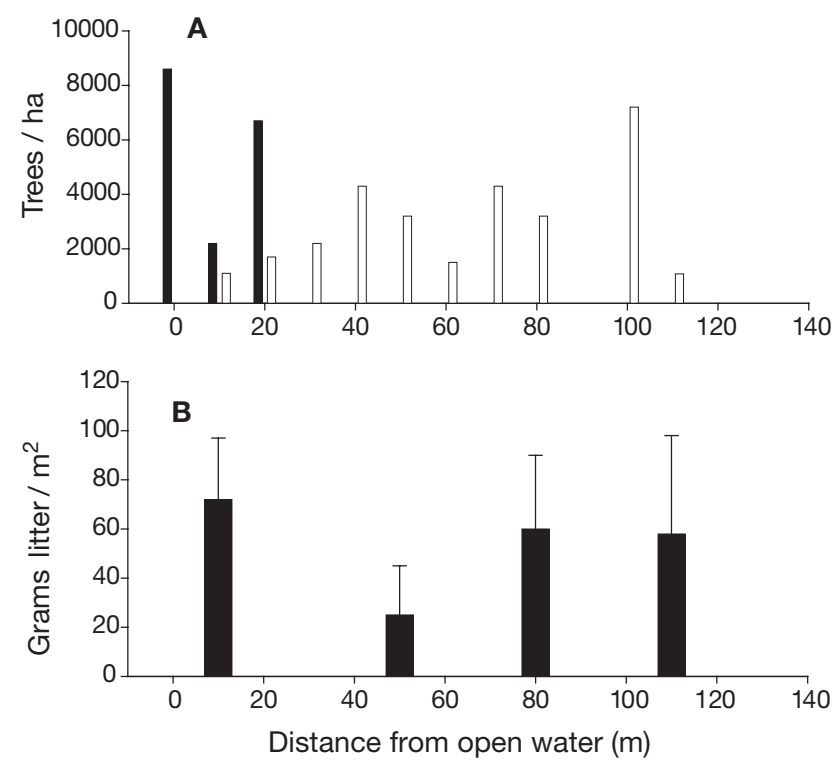

Fig. 2. (A) Rhizophora mangle (solid bars) and Avicennia germinans (open bars). Relative densities of mangroves from forest-open water edge to upland edge. (B) Standing stock of total mangrove leaf litter at 4 sites along the transect 
forest, including the area where the leaf breakdown experiments were conducted (50 to $60 \mathrm{~m}$ from open water). The mean standing crop in the forest ranged from $55.2 \pm 39.7$ to $68.8 \pm 27.1 \mathrm{~g}$ dry wt $\mathrm{m}^{-2}$ over an 18 mo period and was distributed relatively consistently through the 4 stations monitored in the intertidal zone (Fig. 2B). Leaf litterfall over the $60 \mathrm{~d}$ of one decomposition experiment was $1.11 \pm 0.47 \mathrm{~g}$ dry wt $\mathrm{m}^{-2} \mathrm{~d}^{-1}$.

\section{Melampus coffeus population densities}

Melampus coffeus maintained high adult (5 to $19 \mathrm{~mm}$ shell length) densities throughout nearly $3 \mathrm{yr}$ of observations (Fig. 3). MANOVA analysis indicated that densities of juveniles varied with season (February vs May: $F=4.772$, p < 0.035) with densities in February being $2 \times$ those in May, but adult snails densities did not differ with season $(F=0.897, \mathrm{p}=0.349)$. The snails were abundant throughout the intertidal zone (Fig. 3), except for the region within ca. $2 \mathrm{~m}$ of
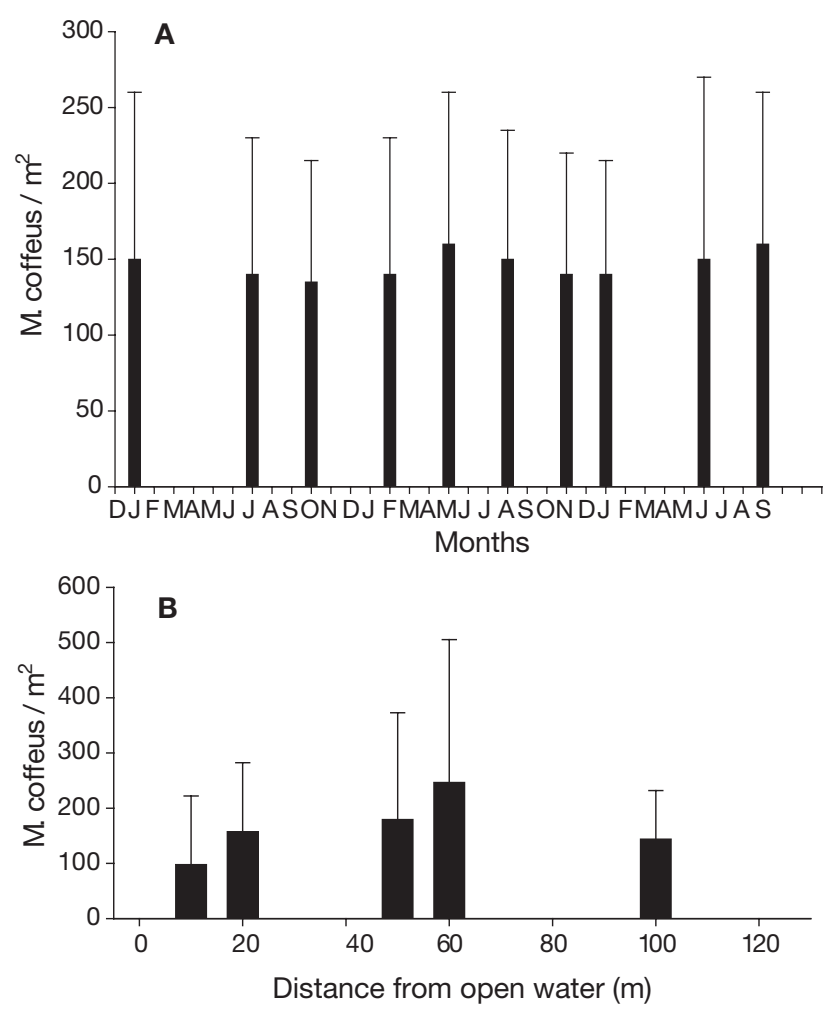

Fig. 3. Melampus coffeus. (A) Numbers per $\mathrm{m}^{2}$ of adult snails in the study forest over nearly 3 yr. (B) Distribution of adult snails at 5 stations in the intertidal zone (130 m wide) in the forest. Distribution of $M$. coffeus observed in the field was from just behind a berm ( 1 to $2 \mathrm{~m}$ in from open water) to the upland edge at about $130 \mathrm{~m}$ from open water open water. The spatial dispersion pattern on the forest floor was very patchy over small scales as $M$. coffeus tended to congregate on leaf litter and to move toward trees and saplings with rising tide. Very small snails ( $<4 \mathrm{~mm}$ shell length) did not climb to avoid rising water, but rather stayed under leaves or within crevices of driftwood when tides were high. The analysis also showed that both juveniles and adults varied with station $(10,30,60,120 \mathrm{~m}$ from open water: juveniles, $F=5.194, \mathrm{p}<0.004$; adults, $F=2.805$, $\mathrm{p}<$ 0.053). For juveniles, there was also a significant season $\times$ station interaction $(F=4.97, \mathrm{p}<0.005)$ mainly caused by very low numbers of juveniles at the station farthest from open water $(120 \mathrm{~m})$ in February but much higher numbers in May. Juvenile and adult densities were not significantly correlated ( $p=0.09$ ). Adult densities were significantly greater than juvenile densities (paired $t$-test, $t=2.11$, df $=44, \mathrm{p}<0.04$ ), although overall mean densities on the forest floor of both groups were relatively high (adults: 142.7 snails $\mathrm{m}^{-2}$; juveniles: 104 snails $\mathrm{m}^{-2}$ ).

\section{Patterns and rates of snail movement in the forest}

Tree DBH and numbers of marked snails on each study tree were: Tree B1, DBH $=4.9 \mathrm{~cm}$, snails $=64$; Tree B2, DBH = $5.1 \mathrm{~cm}$, snails = 97; and Tree B3, DBH = 4.8 , snails $=34$. Distances between these trees were: B1-B2, $2.49 \mathrm{~m}$; B1-B3, $1.64 \mathrm{~m}$; B2-B3, $1.01 \mathrm{~m}$. The total (marked + unmarked) snails on the 3 original trees remained relatively stable over the $31 \mathrm{~d}$ of the study $\left(62.1 \pm 7.7\right.$, range 50.7 to 74.7 snails tree $\left.{ }^{-1}\right)$. During the study, the 195 total snails marked on the 3 trees relocated to trees up to $6.66 \pm 0.60 \mathrm{~m}$ away from their initial tree and populated a total of 33 new trees covering an area of the forest floor of $139 \mathrm{~m}^{2}$ (Fig. 4). However, after $1 \mathrm{mo}, 48.6 \pm 6.1 \%$ of snails were recorded on the tree where they had originally been marked (Fig. 4C).

\section{Leaf tethering and litterbag experiment}

Breakdown of tethered leaves exposed to Melampus coffeus grazing was much more rapid when measured either as dry weight loss (Fig. 5) or area of holes grazed leaves (Fig. 6) than was breakdown of leaves in small, single-leaf bags or groups of leaves in large bags that excluded snails. Leaf breakdown was significantly affected by mangrove species, decomposition treatment, and time main effects and most of their interactions (Table 1).

Avicennia germinans decomposition was much more rapid than that of Rhizophora mangle. For tethered 


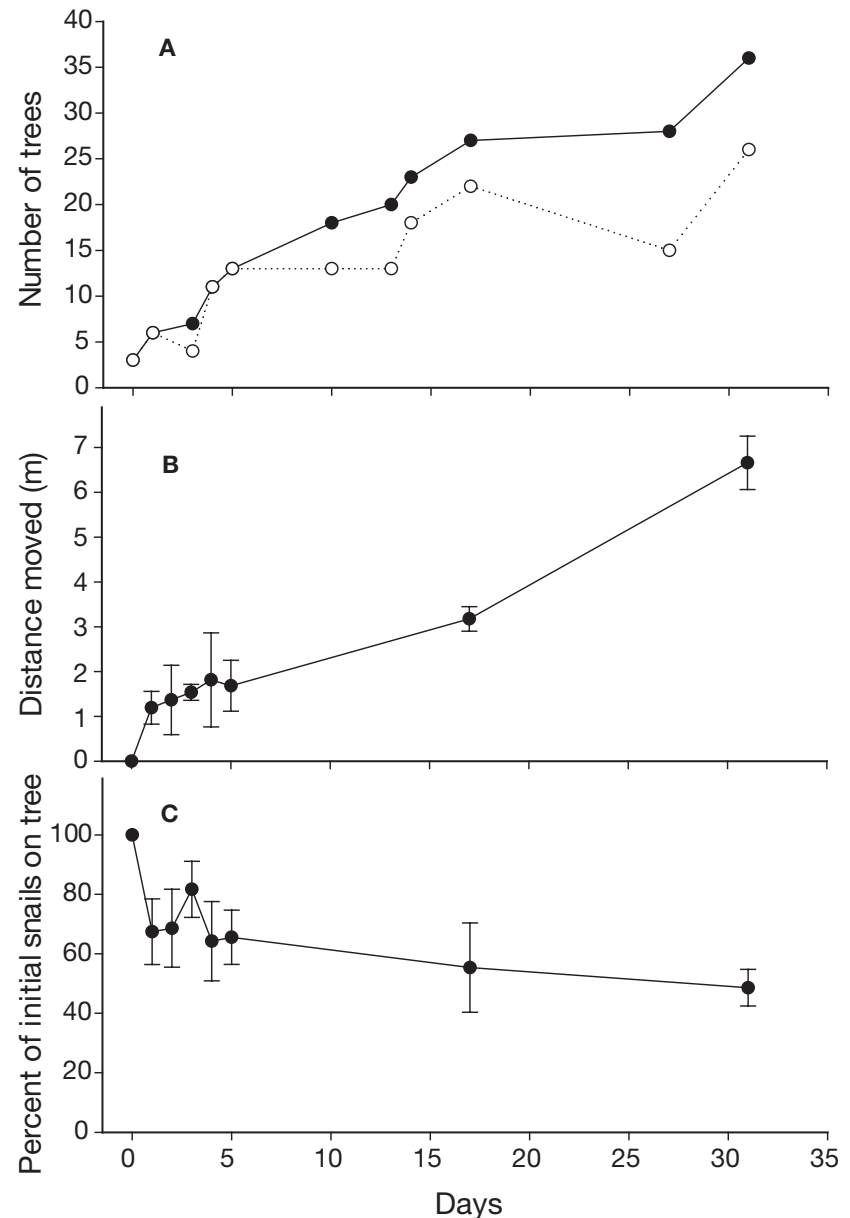

Fig. 4. (A) Number of trees colonized by marked snails over $31 \mathrm{~d}$. (•) Cumulative number of trees with marked snails by that date; $(0)$ number of trees with marked snails on that day of measurement. (B) Distance moved by snails over time. (C) Percent of all snails returning to the initial tree where they were marked at time 0

leaves, $50 \%$ weight loss occurred in 2 wk (A. germinans) and just over 4 wk (R. mangle), while $50 \%$ weight loss of bagged leaves for A. germinans leaves took about 4 to 6 wk depending on bag size, and for $R$. mangle $50 \%$ weight loss of bagged leaves took just over 8 wk (Fig. 5).

\section{Litter accumulation in cages with Melampus coffeus excluded}

Cages excluding Melampus coffeus accumulated significantly more litter over $27 \mathrm{~d}(17.0 \pm 5.03 \mathrm{~g}$ dry wt $\mathrm{m}^{-2}$ ) than did cages in which ambient densities of the snail were maintained $\left(4.44 \pm 2.37 \mathrm{~g}\right.$ dry $\left.\mathrm{wt} \mathrm{m}^{-2}\right)$ (Student's $t$-test, $\mathrm{p}<0.025)$.
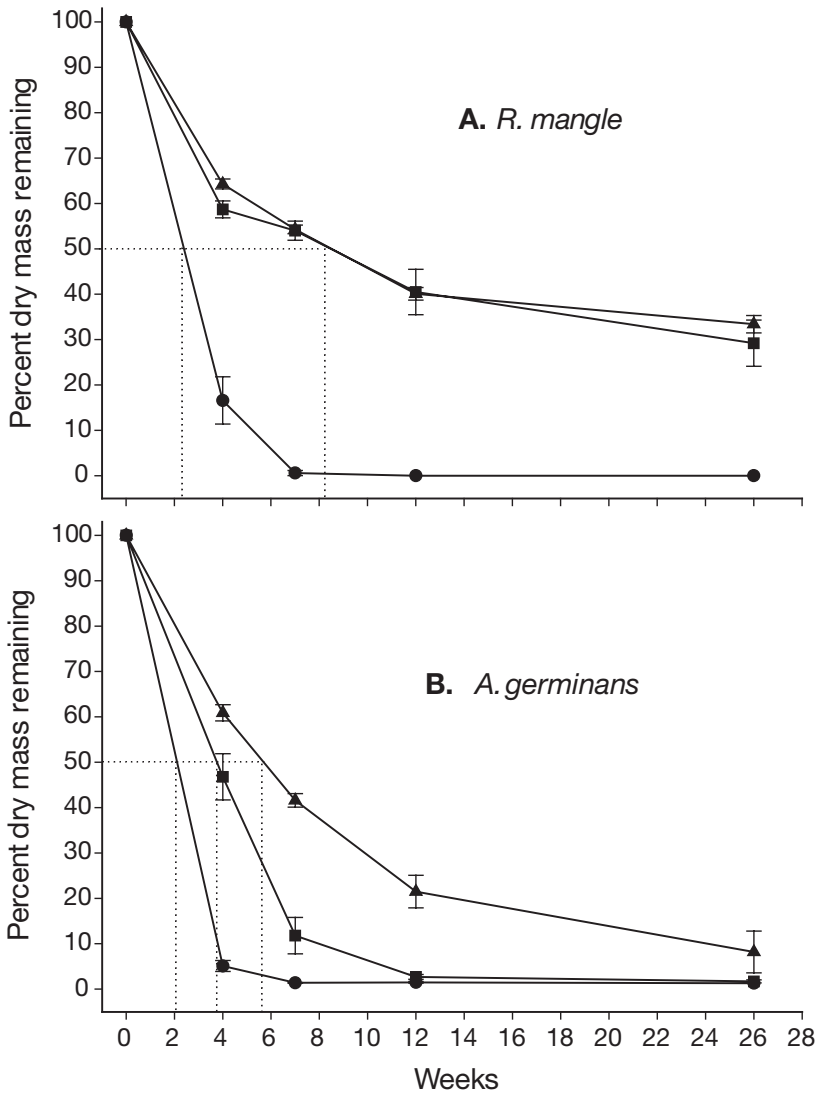

Fig. 5. Percent dry mass remaining for (A) Rhizophora mangle and (B) Avicennia germinans leaves decomposing under unbagged $(\bullet)$, small individual bag $(\boldsymbol{\square})$, or large bag $(\boldsymbol{\Lambda})$ conditions. Dashed lines dropping to the $x$-axis indicate the number of weeks for loss of $50 \%$ of leaf mass

\section{Calculated $\boldsymbol{k}$ values}

Calculated $k$ values for Rhizophora mangle and Avicennia germinans exposed to Melampus coffeus grazing were 0.105 and $0.107 \mathrm{~d}^{-1}$, respectively. The $k$ values for leaves enclosed in small and large litter bags for both species respectively were: A. germinans, 0.022 and $0.014 \mathrm{~d}^{-1}$; and $R$. mangle, 0.006 and $0.005 \mathrm{~d}^{-1}$.

\section{Estimation of amount of standing crop and leaf litterfall consumed by Melampus coffeus}

Experimental leaves were tethered among the natural leaf litter of the forest. Because Melampus coffeus consumes green, yellow, and brown leaves (Proffitt et al. 1993), the rates of grazing measured can be applied to the litter standing crop. Where the decomposition experiment was conducted, mean litter standing crop was $22 \mathrm{~g}$ dry wt $\mathrm{m}^{-2}$ (18.3 $\mathrm{g}$ dry wt $\mathrm{m}^{-2}$ Avicennia ger- 

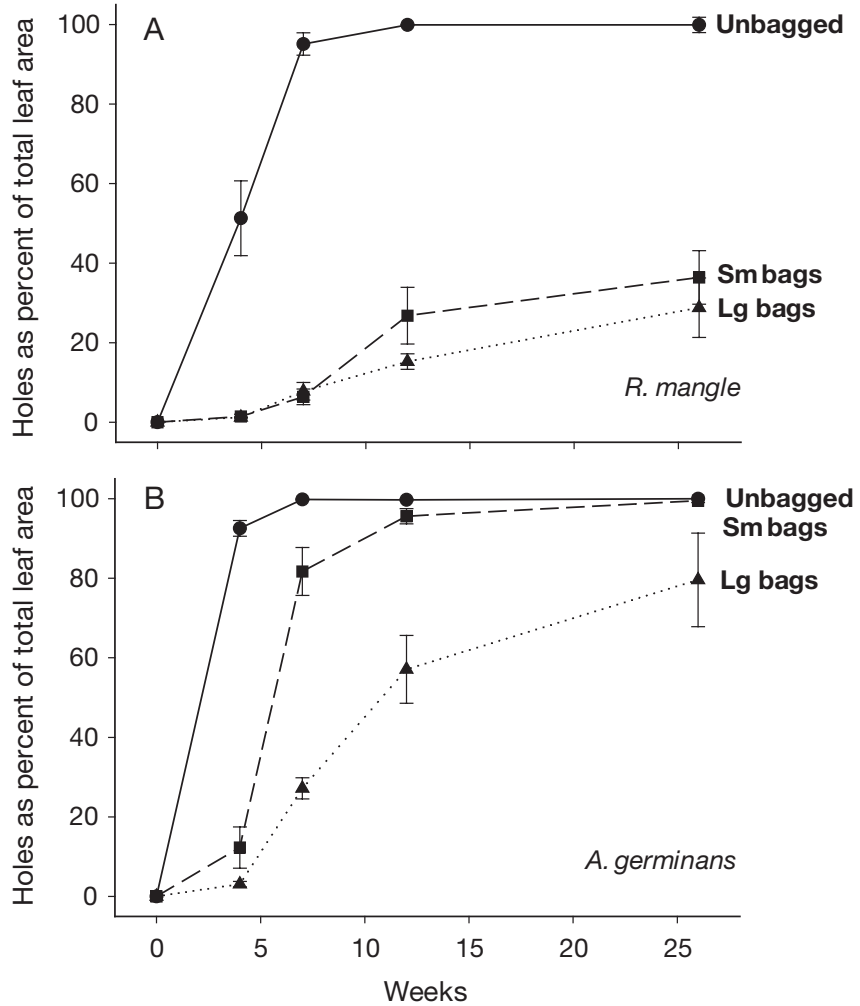

Fig. 6. (A) Rhizophora mangle and (B) Avicennia germinans. Breakdown, as holes in leaves expressed as a percent of total leaf area, for unbagged (tethered), small (Sm) individual bag, and large (Lg) bag treatments for mangrove leaves

minans and $3.7 \mathrm{~g}$ dry $\mathrm{wt} \mathrm{m}^{-2}$ Rhizophora mangle leaves). Conservative estimates of the percent loss per day were made for bagged and tethered leaves from the number of days required for $50 \%$ loss of mass from Fig. 5. These daily loss rates were: $R$. mangle (tethered $=1.7 \% \mathrm{~d}^{-1}$, bagged $=0.89 \% \mathrm{~d}^{-1}$ ) and A. germinans (tethered $=3.5 \% \mathrm{~d}^{-1}$, bagged $=1.19 \% \mathrm{~d}^{-1}$ ). The difference between tethered and bagged values for a spe- cies provides an estimate of the actual daily loss of mass due to grazing $\left(R\right.$. mangle $=0.81 \% \mathrm{~d}^{-1} ;$ A. germinans $=2.31 \% \mathrm{~d}^{-1}$ ). The dry weight of material grazed per day per $\mathrm{m}^{2}$ of forest during the experiment was: $A$. germinans: $18.3 \mathrm{~g} \mathrm{~m}^{-2} \times 2.31 \%$ grazed d $\mathrm{d}^{-1}=0.42 \mathrm{~g} \mathrm{~m}^{-2}$ $\mathrm{d}^{-1}$; R. mangle: $3.7 \mathrm{~g} \mathrm{~m}^{-2} \times 0.81 \%$ grazed $\mathrm{d}^{-1}=0.03 \mathrm{~g}$ $\mathrm{m}^{-2} \mathrm{~d}^{-1}$.

Since litterfall $=1.11 \mathrm{~g} \mathrm{~m}^{-2} \mathrm{~d}^{-1}$ and occurred in the same proportions by species as standing crop, the amount of total leaf fall per day that was consumed by Melampus coffeus is estimated as $0.45 / 1.11=40.5 \%$.

The estimated rate of net accumulation of litter in the forest (net litterfall rate - tethered leaf decomposition rates [i.e. grazed vs microbial and physical combined]) is $1.11-0.703=0.41 \mathrm{~g} \mathrm{~m}^{-2} \mathrm{~d}^{-1}$, in which net accumulation is actual accumulation - tidal export. An estimate of gross accumulation was obtained from the measured litter accumulation rate in the cages in which litter and snails were removed $\left(17 \mathrm{~g} \mathrm{~m}^{-2} / 27 \mathrm{~d}=0.63 \mathrm{~g} \mathrm{~m}^{-2} \mathrm{~d}^{-1}\right)$ and sides prevented the export of all but smallest particles by tides. Thus, about $0.63-0.41=0.22 \mathrm{~g} \mathrm{~m}^{-2} \mathrm{~d}^{-1}$ of litter was exported as particulate material, which was $19.8 \%$ of the leaf litterfall. These estimates are only valid for the time frame of these experiments, and additional studies are needed to examine seasonal effects. Nevertheless, grazing was rapid in late winter-early spring (Proffitt et al. 1993) and summer (present study), and snails were abundant and active in every month of the year. Thus, a high proportion of litterfall appears to be consumed by this Melampus coffeus population in all seasons. An additional area for further research is in the per day consumption rates for leaf litter of different age. Proffitt et al. (1993) found in a laboratory study that $M$. coffeus rapidly grazed fresh, yellow, and brown leaves, although at somewhat different rates. Here, we applied the grazing rate from our experimental leaves to the total standing crop of leaf litter. Although we believe that this provides a good estimate of total consumption, further quantifica-

Table 1. MANOVA results for mangrove leaf litter breakdown for leaves that were tethered or placed in small or large decomposition bags. Dependent variables were percent of leaf area that was translucent, holes in leaves as percent of total area, and percent dry weight loss. Independent variables were decomposition treatment, mangrove species, and time. Percent data were converted to proportions and arcsin(square root) transformed prior to analyses

\begin{tabular}{|c|c|c|c|c|c|c|}
\hline \multirow[t]{2}{*}{ Effect } & \multicolumn{2}{|c|}{ Holes } & \multicolumn{2}{|c|}{ Translucent } & \multicolumn{2}{|c|}{ Weight loss } \\
\hline & $F$ & $\mathrm{p}$ & $F$ & $\mathrm{p}$ & $F$ & $\mathrm{p}$ \\
\hline Species & 160.1 & 0.005 & 18.97 & 0.005 & 52.49 & 0.005 \\
\hline Decomposition treatment & 392.98 & 0.005 & 32.49 & 0.005 & 308.34 & 0.005 \\
\hline Time & 88.28 & 0.005 & 13.38 & 0.005 & 54.11 & 0.005 \\
\hline Species $\times$ Treatment & 59.25 & 0.005 & 17.39 & 0.005 & 69.55 & 0.005 \\
\hline Species $\times$ Time & 2.91 & 0.03 & 3.01 & 0.03 & 1.78 & 0.15 \\
\hline Treatment $\times$ Time & 6.72 & 0.005 & 3.85 & 0.005 & 7.79 & 0.005 \\
\hline Species $\times$ Treatment $\times$ Time & 15.92 & 0.005 & 11.44 & 0.005 & 6.48 & 0.005 \\
\hline
\end{tabular}


tion in the field of rates of grazing on a broader age range of leaf litter will be necessary to refine this estimate.

In summary, an estimated $40.5 \%$ of leaf fall was consumed by Melampus coffeus, where it was converted to snail biomass, eggs and larvae, and snail fecal material. Another $22.8 \%$ of leaf fall biomass was lost to chemical leaching, physical breakdown, and microbial action, and $19.8 \%$ was exported mainly as intact larger pieces of material. Thus, during the experiment, an estimated $16.9 \%\left(0.19 \mathrm{~g} \mathrm{~m}^{-2} \mathrm{~d}^{-1}\right)$ of leaf fall was left to contribute to the leaf litter standing crop. An important unknown is the rate of production and nutrition and energy content of snail fecal material. Because fecal matter funnels into the microbial pathway, and since fecal pellets generally adhere to surfaces, this material may be decomposed in the forest rather than being exported to estuarine waters intact.

\section{DISCUSSION}

The intertidal air-breathing gastropod Melampus coffeus is a critical component in the breakdown of mangrove leaf litter, and it forms an important link between mangrove forest productivity and estuarine food webs. Although a number of other invertebrate species act to accelerate litter breakdown in mangrove and salt-marsh systems (e.g., shredder snails, sesarmid crabs), $M$. coffeus belongs to a smaller group that can directly assimilate the resources in mangrove leaves (Mook 1986). Hence, where $M$. coffeus is a dominant littervore, substantial portions of mangrove leaf material are converted to snail biomass and larvae. Adult snails are preyed upon by white ibis Eudocimus albus) (authors' pers. obs.); juvenile snails may be preyed on by killifish Fundulus heteroclitus, which we have observed foraging in the leaf litter at high tide; and larvae are exported to the estuary (Apley 1968).

We found that Melampus coffeus, which maintained high population densities throughout most of the intertidal zone over a 3 yr study, was very active in terms of movement and leaf-grazing on the forest floor at low tide. We estimated that $40.5 \%$ of leaf litterfall was consumed by $M$. coffeus during our late summer-early fall decomposition studies. Similar to results of Proffitt et al. (1993), we found that Avicennia germinans leaves were consumed more rapidly than Rhizophora mangle leaves. Proffitt et al. (1993) also found high grazing rates in a winter field experiment at this same site. McKee \& Faulkner (2000) reported high rates of grazing, mainly by $M$. coffeus, at 2 sites in SW Florida and low rates at 2 other sites. They found that leaves of $A$. germinans and $L$. racemosa were consumed more rapidly than those of $R$. mangle, and that grazing dif- fered between years. The high percentage of litterfall consumed by $M$. coffeus in Florida was similar to values reported for crabs in the Indo-Pacific. Robertson (1986) reported that crabs consumed $28 \%$ of leaf fall in Australia, Lee (1989) found that crabs removed $57 \%$ of leaf litter produced by the mangrove Kandelia candel, and Emmerson \& McGwynne (1992) showed that $44 \%$ of Avicennia marina litter was consumed by crabs. Twilley et al. (1997) reported that a crab harvested most leaves during the rainy season in a forest in Ecuador. Middleton \& McKee (2001) compared tethered and bagged leaves in Belize and found that crabs were responsible for considerable fraction of leaf mass loss and that gammarid amphipods also contributed to leaf degradation. The leaf mass consumed per day by crabs in Belize (Middleton \& McKee 2001) was less than that consumed by $M$. coffeus in the present study (R. mangle leaves: 0.175 vs $0.81 \%$; A. germinans leaves: 0.348 vs $2.31 \%$ ). Percent removed per day by crab grazing in the lower intertidal zone in Belize reported by Middleton \& McKee (2001) was similar to grazing rates by $M$. coffeus in Tampa Bay averaged over the different species of mangrove leaves in the 2 studies (Belize 1.96\% vs Tampa Bay $1.56 \%$ grazed $\mathrm{d}^{-1}$ ). However, grazing by $M$. coffeus occurred throughout the intertidal zone, while the high grazing in Belize was restricted to the lower intertidal.

Rates of decomposition ( $k$ values) of leaves in litterbags in our study were similar to literature values (Fig. 7). The $k$ values for both Rhizophora mangle and Avicennia germinans exposed to Melampus coffeus grazing were greater than $k$ values from litter in either small or large bags. Comparison of our data with other studies of mangrove decomposition indicates that litterbag studies that exclude detritivores have much slower decomposition rates (Fig. 7). The typical $k$ ranges for the 2 species were as follows: 0.0026 to $0.0061 \mathrm{~d}^{-1}$ (R. mangle) and 0.0037 to $0.027 \mathrm{~d}^{-1}$ (A. germinans), when measured in litterbags (Fig. 7). Twilley et al. (1997) found differences in the rate of $R$. mangle decomposition in Ecuador between wet $\left(k=0.011 \mathrm{~d}^{-1}\right)$ and dry $\left(k=0.006 \mathrm{~d}^{-1}\right)$ seasons. However, their highest value is $10 \times$ less than for leaves exposed to $M$. coffeus in our present study. Twilley et al. (1997) reported that the crab Ucides cordatus relocated most leaves to its burrow during the rainy season (January to June) and that the great tidal range transported most leaves to the estuary during the time of reduced crab activity.

The closely related Melampus bidentatus produces 33150 eggs snail ${ }^{-1} \mathrm{yr}^{-1}$ (Apley 1968). M. coffeus lay similar numbers of eggs in gelatinous masses under leaves and on decaying wood (Russell-Hunter et al. 1972). Since the snails are simultaneous hermaphrodites, it is possible that a population averaging 100 snails $\mathrm{m}^{-2}$ could produce some $3 \times 10^{6}$ larvae $\mathrm{m}^{-2} \mathrm{yr}^{-1}$. 

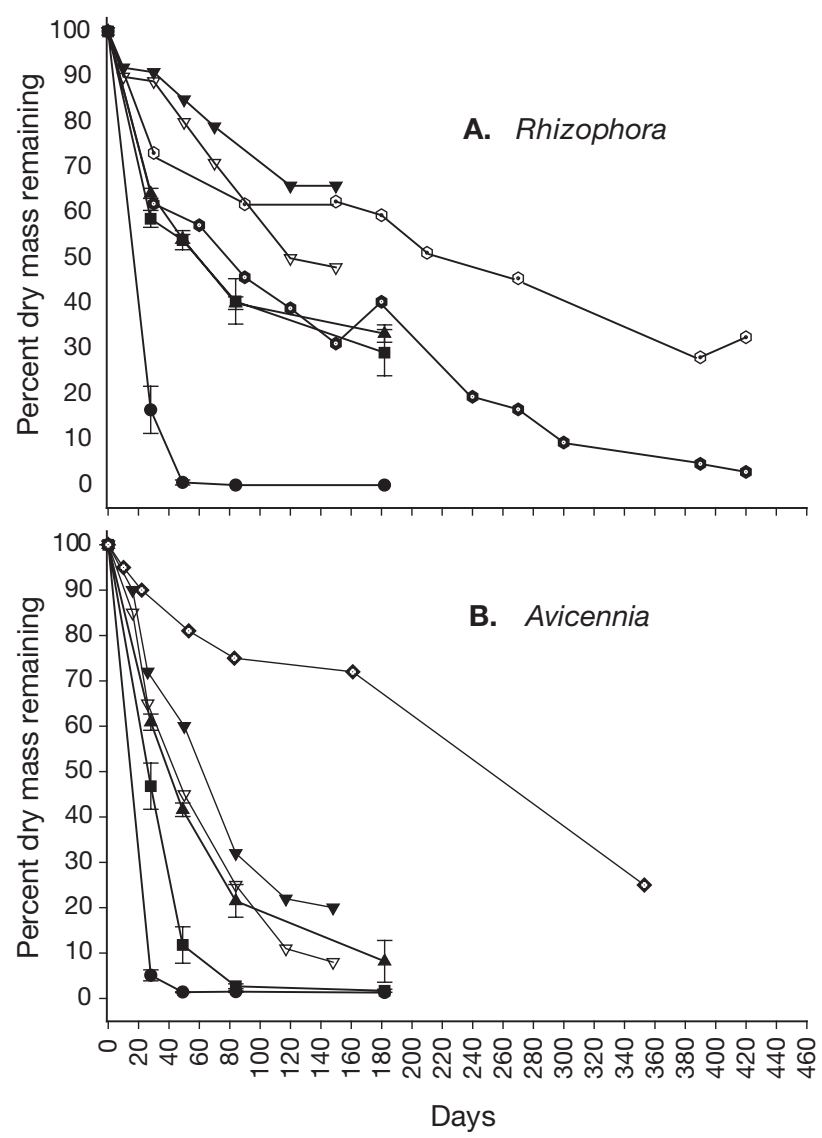

Fig. 7. Percent dry mass remaining for (A) Rhizophora mangle and (B) Avicennia germinans leaves. Present study data are unbagged $(\bullet)$, small individual bags $(\boldsymbol{\bullet})$, or large bags $(\boldsymbol{\bullet})$. (A) also contains data from Heald (1969) ( $\bullet=$ dry area, $\bullet=$ wet brackish) and Twilley et al. (1986) $(\nabla=$ mixed species plot, $\mathbf{\nabla}=$ monospecific plot at Rookery Bay). (B) also contains data from Twilley et al. (1986) $(\bullet=$ their RB1 mixed site, $\boldsymbol{\nabla}=$ their RB2 monospecific site, $\nabla=$ their RB2 mixed site), June trials

These larvae are exported via the tide and spend 4 to $6 \mathrm{wk}$ in the planktonic food web of the estuary before the survivors return on a spring high tide to metamorphose into juvenile snails (Apley 1968, Holle \& Dineen 1957). Thus, a substantial proportion of the export of nutrient and energy resources from mangrove leaf litter is in the form of snail larvae in the Tampa Bay estuary.

Acknowledgements. We wish to thank the management of War Veterans Park for providing access to the study site. Students at St. Petersburg Junior College who assisted in field vegetation analyses included: B. Cochrane, K. Johns, D. Jones, C. Holmes, T. Penkethman, B. Larson, A. Goodman, K. Darovec, D. Smith, and K. Kowzan. B. Middleton, K. McKee, and B. Vairin provided very helpful comments on versions of the manuscript as did 3 anonymous reviewers. We thank D. Johnston at the National Wetlands Research Center for conducting a statistical review.

\section{LITERATURE CITED}

Apley ML (1968) Field and experimental studies on pattern and control of reproduction in Melampus bidentatus (Say). $\mathrm{PhD}$ thesis, Syracuse University, Syracuse, NY

Barlocher F, Newell SY (1994) Growth of the salt marsh periwinkle Littoraria irrorata on fungal and cordgrass diets. Mar Biol 118:109-114

Boto KG (1992) Nutrients and mangroves. In: Connell DW, Hawker DW (eds) Pollution in tropical aquatic systems. CRC Press, Boca Raton, FL, p 129-145

Cundell AM, Brown MS, Stanford R, Mitchell R (1979) Microbial degradation of $R$. mangle leaves immersed in the sea. Estuar Coast Mar Sci 9:281-286

Emmerson WD, McGwynne LE (1992) Feeding and assimilation of mangrove leaves by the crab Sesarma meinerti in relation to leaf-litter production in Mgazana, a warmtemperate southern African mangrove swamp. J Exp Mar Biol Ecol 157:41-53

Fell JW, Master IM (1973) Fungi associated with the degradation of mangrove (Rhizophora mangle L.) leaves in south Florida. In: Stevenson LH, Colwell RR (eds) Estuarine microbial ecology. Univ of South Carolina Press, Columbia, SC, p 455-465

Fenchel T (1969) The ecology of marine microbenthos. II. The food of marine benthic ciliates. Ophelia 5:73-121

Fenchel T (1970) Studies on the decomposition of organic detritus derived from the turtle grass, Thalassia testudinum. Limnol Oceanogr 15:14-20

Golley FB (1960) Ecologic notes on Puerto Rican Mollusca. Nautilus 73:152-155

Heald EJ (1969) The production of organic detritus in a south Florida estuary. PhD thesis, Univ of Miami, FL

Heald EJ (1971) The production of organic detritus in a south Florida estuary. Univ of Miami Sea Grant Tech Bull No. 6

Heard RW (1982) Guide to common tidal marsh invertebrates of the northeastern Gulf of Mexico. Mississippi Alabama Sea Grant Consortium Publ No. MASGP-79004, Dauphin Island, AL

Holle PA, Dineen CF (1957) Life history of the salt marsh snail, Melampus bidentatus Say. Nautilus 70:90-95

Holmer M, Olsen AB (2002) Role of decomposition of mangrove and seagrass detritus in sediment carbon and nitrogen cycling in a tropical mangrove forest. Mar Ecol Prog Ser 230:87-101

Lee SY (1989) The importance of sesarminae crabs Chiromanthes spp and inundation frequency on mangrove (Kandelia candel (L) Druce) leaf litter turnover in a Hong Kong tidal shrimp pond. J Exp Mar Biol Ecol 131: 23-43

Leh CMU, Sasekumar A (1985) The food of sesarmid crabs in Malaysian mangrove forests. Malay Nat J 39:135-145

Lugo AE, Snedaker SC (1974) Ecology of mangroves. Annu Rev Ecol Syst 5:39-64

Macnae W (1967) Zonation within mangroves associated with estuaries in North Queensland. In: Lauff GH (ed) Estuaries. Publ No. 83. American Association for the Advancement of Science, Washington, DC, p 432-441

Mason CF (1974) Decomposition of angiosperm tree leaf litter: Mollusca. In: Dickinson CH, Pugh GJF (eds) Biology of plant litter decomposition, Vol 2. Academic Press, New York, p 555-591

McKee KL, Faulkner P (2000) Restoration of biogeochemical function in mangrove forests. Restor Ecol 8:247-259

Middleton BA, McKee KL (2001) Dregadation of mangrove tissues and implications for peat formation in Belizean island forests. J Ecol 89:818-828 
Mook D (1986) Absorption efficiencies of the intertidal mangrove dwelling mollusk Melampus coffeus Linne and the rocky intertidal mollusk Acanthopleura granulata Gemlin. PSZN I: Mar Ecol 7:105-113

Mook MS (1973) Intertidal zonation of Melampus bidentatus Say and Melampus coffeus L. (Gastropoda: Pulmonata). MS thesis, University of South Florida, Tampa, FL

Morton JE (1955) The evolution of the Ellobiidae. Proc Zool Soc Lond 125:127-168

Newell R (1965) The role of detritus in the nutrition of two marine deposit feeders, the prosobranch Hydrobia ulvae and the bivalve Macoma balthica. Proc Zool Soc Lond 144: $25-45$

Newell SY, Barlocher F (1993) Removal of fungal and total organic matter from decaying cordgrass leaves by shredder snails. J Exp Mar Biol Ecol 171:39-49

Odum WE, Heald E J (1972) Trophic analyses of an estuarine mangrove community. Bull Mar Sci Gulf Caribb 22:671-738

Poovachiranon S, Boto KG, Duke NC (1986) Food preference studies and ingestion rate measurements of the mangrove amphipod Parhyale hawaiensis (Dana). J Exp Mar Biol Ecol 98:129-140

Proffitt CE, Johns KM, Cochrane CB, Devlin DJ and 5 others (1993) Field and laboratory experiments on the consumption of mangrove leaf litter by the macrodetritivore Melampus coffeus L (Gastropoda: Pulmonata). Fla Sci 56(4):211-222

Robertson AI (1986) Leaf-burying crabs: their influence on

Editorial responsibility: Kenneth L. Heck (Contributing

Editor), Dauphin Island, Alabama, USA energy flow and export from mixed mangrove forests (Rhizophora spp.) in northeastern Australia. J Exp Mar Biol Ecol 102:237-248

Robertson AI, Alongi DM, Boto KG (1992) Food chains and carbon fluxes. In: Robertson AI, Alongi DM (eds) Tropical mangrove ecosystems. Coastal and Estuarine Studies Series No 41. American Geophysical Union, Washington, DC, p 293-326

Russell-Hunter WD, Apley ML, Hunter RD (1972) Early lifehistory of Melampus and the significance of semilunar synchrony. Biol Bull (Woods Hole) 143:623-656

Smith TJ III, Chan HT, McIvor CC, Robblee MB (1989) Comparisons of seed predation in tropical, tidal forests on three continents. Ecology 70:146-151

Snedaker SA, Lugo A (1973) The role of mangrove ecosystems in the maintenance of environmental quality and a high productivity of desirable fisheries. US Bureau of Sports Fisheries and Wildl NITS, Springfield, MA

Twilley, RR, Lugo AE, Patterson-Zucca C (1986) Litter production and turnover in basin mangrove forests in southwest Florida. Ecology 67:670-683

Twilley RR, Pozo M, Garcia VH, Rivera-Monroy VH, Zambrano R, Bodero A (1997) Litter dynamics in riverine mangrove forests in the Guayas River estuary, Ecuador. Oecology 111:109-122

Van der Valk AG, Attiwill PM (1984) Decomposition of leaf and root litter of Avicennia marina at Westport Bay, Victoria, Australia. Aquat Bot 18:205-221

Submitted: July 14, 2003; Accepted: March 9, 2005

Proofs received from author(s): June 28, 2005 